GRASAS Y ACEITES 71 (4)

October-December 2020, e375

ISSN-L: 0017-3495

https://doi.org/10.3989/gya.0564191

\title{
Development of zero-trans shortenings with high thermo-oxidative stability by enzymatic transesterification
}

\author{
E. Gruczynska-Sekowska ${ }^{\mathrm{a},}$, F. Aladedunye ${ }^{\mathrm{b}, \mathrm{c}}$, F. Anwar ${ }^{\mathrm{d}}$, P. Koczon $^{\mathrm{a}}$, D. Kowalska ${ }^{\mathrm{a}}$, \\ M. Kozlowska ${ }^{\mathrm{a}}$, E. Majewska ${ }^{\mathrm{a}}$ and K. Tarnowska ${ }^{\mathrm{a}}$ \\ ${ }^{a}$ Department of Chemistry, Institute of Food Sciences, Warsaw University of Life Sciences (WULS-SGGW), \\ Nowoursynowska 159C, 02-776 Warsaw, Poland \\ ${ }^{\mathrm{b}}$ Department of Human Nutritional Sciences, 209 Human Ecology Building, \\ University of Manitoba, Winnipeg, Manitoba MB R3T 2N2, Canada \\ ${ }^{\mathrm{c}}$ Feal Stability Consultants, Lethbridge, Alberta, Canada \\ ${ }^{\mathrm{d}}$ Department of Chemistry, University of Sargodha, University Road, Sargodha 40100, Pakistan \\ ${ }^{\otimes}$ Corresponding author: eliza_gruczynska@sggw.edu.pl; egruczynska@protonmail.ch
}

Submitted: 07 May 2019; Accepted: 26 September 2019; Published online: 29 September 2020

SUMMARY: Novel zero-trans frying shortenings were formed by enzymatic transesterification by exploring a palm stearin and canola oil mixture and stearic acid as substrates. Both immobilized (Novozym 435, Lipase PS "Amano" IM) and non-immobilized (Lipomod TM 34P) enzymes were applied as biocatalysts. Palmitic acid, the fatty acid which defines the proper type of crystal formation, was present at the $15 \%$ level in the reaction mixtures. The novel structured lipids had comparable physical properties and offered similar frying performance to those of commercial shortening. Needle-shaped crystals were predominant both in the transesterification products and the commercial frying shortening. Furthermore, solid fat content profiles of the zero-trans structured lipids produced by Novozym 435 and Lipase PS "Amano" IM were close to those of the commercial shortening.

KEYWORDS: Canola oil; Enzymatic transesterification; Frying; Palm stearin; Stearic acid; Zero-trans shortening

RESUMEN: Obtención de shortenings cero-trans con alta estabilidad termo-oxidativa por transesterificación enzimática. Los innovadores shortenings cero-trans para frituras se obtenían por transesterificación enzimática utilizando como sustratos una mezcla de estearina de palma con aceite de cánola y ácido esteárico. Tanto las enzimas inmovilizadas (Novozym 435, Lipase PS “Amano" IM) como las no inmovilizadas (Lipomod TM 34P) fueron aplicadas como biocatalizadores. El contenido de ácido palmítico, el ácido graso que define el tipo adecuado de formación cristalina, fue del 15\% en las mezclas de reacción. Los lípidos estructurados innovadores tenían propiedades físicas comparables a los shortenings comerciales y estabilidad de oxidación térmica similar en proceso de fritura. Los cristales en forma de aguja predominaban tanto en los productos de transesterificación como en los shortenings para frituras disponible en el mercado. Además, los perfiles de contenido de grasa sólida de los lípidos estructurados cero trans producidos por Novozym 435 y Lipase PS "Amano" IM eran similares a los perfiles de los shortenings comerciales.

PALABRAS CLAVE: Aceite de cánola; Ácido Esteárico; Cero-trans shortening; Estearina de palma; Fritura; Transesterificación enzimática

ORCID ID: Gruczynska-Sekowska E https://orcid.org/0000-0003-3309-9425, Aladedunye F https://orcid.org/00000002-5091-5618, Anwar F https://orcid.org/0000-0002-2704-7947, Koczon P https://orcid.org/0000-0002-84496933, Kowalska D https://orcid.org/0000-0002-3680-636X, Kozlowska M https://orcid.org/0000-0002-9252-3268, Majewska E https://orcid.org/0000-0002-5910-1119, Tarnowska K https://orcid.org/0000-0002-8459-9019

Citation/Cómo citar este artículo: Gruczynska-Sekowska E, Aladedunye F, Anwar F, Koczon P, Kowalska D, Kozlowska M, Majewska E, Tarnowska K. 2020. Development of zero-trans shortenings with high thermo-oxidative stability by enzymatic transesterification. Grasas Aceites 71 (4), e375. https://doi.org/10.3989/gya.0564191

Copyright: (C2020 CSIC. This is an open-access article distributed under the terms of the Creative Commons Attribution 4.0 International (CC BY 4.0) License. 


\section{INTRODUCTION}

Commercial shortenings, commonly used in the food industry, are most often generated using hydrogenation, which is the source of trans fatty acids(TFA). Many scientific studies indicate a strong association of the consumption of trans isomers with the risk of developing coronary heart diseases (Eckel et al., 2007), type 2 diabetes and colon and prostate gland cancer as well as allergies (Chavarro et al., 2008). The American Heart Association Nutrition Committee (Lichtenstein et al., 2006) and World Health Organization (Uauy et al., 2009) recommend that the consumption of TFA should be less than $1 \%$ of the total daily energy intake. Transesterification became a useful alternative to hydrogenation, especially because trans fatty acids are not formed and biologically active fatty acids remain intact during this process. Furthermore, both chemical and enzymatic transesterification show great potential for obtaining lipids with a pre-determined composition and triacylglycerol structure and thus, with desirable properties and nutritionally beneficial constitution.

When preparing shortenings, both physical and nutritional aspects must be taken into account (Ahmadi and Marangoni, 2009). A typical characteristic of well-designed plastic shortenings should also be a natural tendency to crystallize in the polymorphic form of $\beta$ ' (Idris et al., 1989). The palmitic acid content in the reactants and its position in the triacylglycerol molecules determine the morphology of crystals and their type of dominant polymorphic form. In this paper the use of the palm stearin and canola oil mixture structured with stearic acid was described to obtain highly stabile zero-trans structured lipids. The palm stearin in this mixture was the source of palmitic acid, which assured the desired form of lipid crystallization (deMan, 1992). In turn, canola oil has the proper $\omega-6 / \omega-3$ acids ratio and delivers oleic acid, which is stable against oxidation and has beneficial effects on human health (Ahmadi and Marangoni, 2009). As per stearic acid, the results of early research by Hegsted et al., (1965) showed its neutral effect on serum cholesterol levels. Moreover, other investigations indicate that stearic acid has an even hypocholesterolemic effect compared to other saturated fatty acids (Bonanom and Grundy, 1988).

The main aim of this study was to obtain zero-trans structured lipids with similar frying performance and physical properties to commercial frying shortening. Consequently, the suitability of the enzymes used as biocatalysts was assessed, which brings additional value to the present work, especially in that, to the best of the authors' knowledge, never before have any of the enzymes studied here been applied as biocatalyst for frying shortening formulations. Novozym 435 and Lipase PS "Amano" IM are widely used in organic syntheses, including transesterification; whereas Lipomod TM 34P is not often employed as a catalyst for the transesterification process. The tested enzymes vary in specificity and contain different amounts of water, which is a profound factor in the catalytic activity of enzymes and consequently the properties of final reaction products. Therefore, it seemed promising to check the suitability of all these lipases for the development of shortenings for high temperature applications.

The functionality of the final transesterification products was assessed on the basis of fatty acid composition, triacylglycerol composition, solid fat content, actual crystal morphology and the frying performance of developed structured lipids.

\section{MATERIALS AND METHODS}

\subsection{Materials}

Palm stearin (PS) and commercially refined, bleached and deodorized regular canola oil (CAN) were generously provided by Richardson Oilseed Processing (Lethbridge, Canada). The PS and CAN mixture containing $15 \%$ (by weight) palmitic acid was structured with stearic acid by enzymatic transesterification. Stearic acid was purchased from Sigma-Aldrich Chemical Co. (St Louis, MO, USA). All chemicals and solvents used in this study were of analytical grade. Standards of triacylglycerols were purchased from Larodan Fine Chemicals AB (Malmö, Sweden). Tocopherol standards were obtained from Calbiochem-Novabiochem (San Diego, CA, USA). Standards of fatty acid methyl esters were purchased from Nu-Chek-Prep Inc. (Elysian, MN, USA).

\subsection{Biocatalysts}

Both immobilized (Novozym 435, Lipase PS "Amano" IM) and non-immobilized (Lipomod TM 34P) lipases were applied as biocatalysts for enzymatic transesterification.

Novozym 435 is a B-fraction of thermostable lipase from Pseudomonas antarctica immobilized on a macroporous acrylic resin. It contains $2.0 \%$ water. Depending on the reagents used it may show sn-1,3 regiospecificity or act as a non-specific lipase.

Lipase PS "Amano" IM is a lipolytic enzyme immobilized on diatomaceous earth whose biological source is the Burkholderia cepacia strain. Its water content is $1.5 \%$. It is a sn- 1,3 regiospecific preparation.

Lipomod TM 34P is a lipolytic native enzyme whose active component is Candida rugosa lipase. It contains $6.9 \%$ water. It does not show positional specificity. 
Lipase PS "Amano" IM was purchased from Amano Enzyme USA Co. Ltd (Elgin, IL, USA). Novozym 435 was kindly donated by Sigma-Aldrich Chemical Co. (St Louis, MO, USA). Lipomod TM $34 \mathrm{P}$ was generously provided by Biocatalysts Ltd (Cardiff, Wales, UK).

\subsection{Transesterification}

Three sets (for triplicate repetition of reaction) of three vials each (for three different enzymes) were filled with the mixture of palm stearin and canola oil. Then stearic acid was added to each vial in such a quantity that the total content of saturated acids in the reaction mixture remained at 25\% (by weight). Each vial was flushed with nitrogen to limit the presence of moisture and air and then placed in a hybridization oven (Tek Star, Greensboro, NC, USA) set to $70^{\circ} \mathrm{C}$. As soon as thermal equilibrium was reached, catalysts were added at $8 \%$ (by weight). Transesterification reactions were performed under agitation for $8 \mathrm{~h}$, after which the enzymes were removed by filtration and the reactions were stopped. In order to remove unreacted fatty acids, the transesterification products were dissolved in a mixture of diethyl ether with ethanol (1:1, by volume) and unreacted fatty acids were neutralized with a $0.1 \mathrm{M}$ solution of potassium hydroxide to the phenolphthalein endpoint. Then the mixture was transferred to a separatory funnel and thoroughly mixed with diethyl ether. The lower aqueous layer was separated and discarded. The upper organic layer, containing acylglycerols, was passed through a bed of anhydrous magnesium sulphate. After the evaporation of diethyl ether transesterification structured acylglycerols were separated into triacylglycerols (TAGs) and non-TAG fractions as described by Kowalska et al., (2014) and TAG fractions were further analyzed.

\subsection{Fatty acid composition}

Fatty acids were methylated prior to analysis by gas chromatography (GC) based on the AOCS Official Method Ce 1-62 (Firestone, 2009). The resulting fatty acid methyl esters (FAME) were analyzed on a Trace GC Ultra gas chromatograph (Thermo Electron S.p.a, Rodano, Italy) using a Trace TR-FAME fused silica capillary column $(100 \mathrm{~m} \times 0.25 \mathrm{~mm}, 0.25 \mu \mathrm{m}$; Thermo, Waltham, MA, USA). Hydrogen was used as carrier gas at a flow rate of $1.5 \mathrm{~mL} / \mathrm{min}$. Column temperature was programmed from 70 to $160{ }^{\circ} \mathrm{C}$ at $25^{\circ} \mathrm{C} / \mathrm{min}$, then held for 30 minutes, and further programmed to $210{ }^{\circ} \mathrm{C}$ at $3{ }^{\circ} \mathrm{C} / \mathrm{min}$. Initial and final temperatures were held for 5 and 30 minutes, respectively. Splitless injection was used with a PTV injector. The detector temperature was set at $250^{\circ} \mathrm{C}$. FAME samples, $1 \mu \mathrm{L}$ each, were injected with a AS 3000 autosampler (Thermo Electron S.p.a, Rodano, Italy). For each specific sample the whole analysis process was repeated three times. Fatty acids were identified by the comparison of retention time with authentic standards (standard mixture \#617; Nu-Chek-Prep Inc., Elysian, MN, USA).

\subsection{Triacylglycerol composition}

The composition of triacylglycerols was analyzed using reverse phase high performance liquid chromatography (RP-HPLC) with a Finnigan Surveyor liquid chromatograph (Thermo Electron Corporation, Waltham, MA, USA). Two columns connected in series (Gemini 110A, $250 \times 3 \mathrm{~mm}$, $5 \mu \mathrm{m}$; Phenomenex, Torrance, CA, USA) were used to separate TAGs. Each analyzed sample of $10 \mu \mathrm{L}$ injection was subjected to the following gradient elution: $70 \%$ acetonitrile $/ 30 \%$ dichloromethane held for $15 \mathrm{~min}$; to $60 \%$ acetonitrile $/ 40 \%$ dichloromethane at $25 \mathrm{~min}$, held for $35 \mathrm{~min}$; to $40 \%$ acetonitrile $/ 60 \%$ dichloromethane at $50 \mathrm{~min}$, held for $55 \mathrm{~min}$; to $30 \%$ acetonitrile $/ 70 \%$ dichloromethane at $60 \mathrm{~min}$, held for $65 \mathrm{~min}$; and back to $70 \%$ acetonitrile/30\% dichloromethane at $85 \mathrm{~min}$, held for $90 \mathrm{~min}$ at a flow rate of $0.4 \mathrm{~mL} / \mathrm{min}$. Eluted components were detected with an evaporative light scattering detector (Sedex 75; Sedere, Alfortville, France), operated at $40{ }^{\circ} \mathrm{C}$ with air pressure of $2.5 \times 10^{5}$ $\mathrm{N} / \mathrm{m}^{2}$. For each specific sample the whole analysis process was repeated three times. TAGs were identified by comparison of the retention times of authentic standards (Nu-Chek-Prep Inc., Elysian, $\mathrm{MN}$, USA), calculated as relative retention time to triolein.

\subsection{Physical measurements}

The solid fat content (SFC, \%) was measured by pulse nuclear magnetic resonance ( $\mathrm{p}-\mathrm{NMR}$ ) with a Bruker PC/20 Series NMR Analyzer (Bruker Optics, Milton, ON, Canada). Measurements were repeated three times and final results were averaged. Initially, to erase any crystal history, the samples were held at $80^{\circ} \mathrm{C}$ for $30 \mathrm{~min}$. The melted fats were then placed in NMR tubes and submitted to the tempering treatments as specified in the AOCS Official Method Cd 16-81 (Firestone, 2009).

Crystal morphology was observed and recorded in polarized light at two different temperatures $\left(5\right.$ and $25^{\circ} \mathrm{C}$ ) in order to assess the effect of crystallization temperature. Briefly, a drop of pre-heated fat $\left(80^{\circ} \mathrm{C}\right)$ was placed on slide which was pre-heated to the same temperature and then gently cover slipped. Each slide was cooled down and kept for $48 \mathrm{~h}$ at one of the desired temperatures and then microscopic images were recorded at $\times 40$ magnification using an Olympus BH polarized light microscope (Olympus, Tokyo, Japan) equipped with a Sony XC-75 CCD video camera (Sony Corporation, Japan). 


\subsection{Model frying fast test}

Structured lipids were tested for frying performance with a model frying fast test as described by Aladedunye and Przybylski (2011). Briefly $12 \mathrm{~g}$ of transesterification products were weighed into a glass beaker (Pyrex, USA; outer diameter $35 \mathrm{~mm}$, capacity $30 \mathrm{~mL})$. Octagonal stir bars $(9.5 \times 25 \mathrm{~mm}$, Fischer Scientific, USA) were placed into the vessel, increasing the final surface to volume ratio to 0.42 . Then the vessel was heated and, while kept at $180 \pm 5^{\circ} \mathrm{C}$ for $10 \mathrm{~min}$, a $1.2 \mathrm{~g}$ sample of formulated starch (a mixture of potato starch, glucose and silica gel at 4:1:1, by weight) was added. The temperature was then maintained at the same level for $2 \mathrm{~h}$ with intermittent stirring at $400 \mathrm{rpm}$ for $20 \mathrm{~min} .0 .5-\mathrm{mL}$ oil samples were withdrawn after the 30th, 70th and 120 th min of heating. The frying performance of fats was assessed by the measurement of total polar compounds, composition of polar compounds and analysis of residual tocopherols.

\subsubsection{Total polar compounds (TPCs)}

TPCs were determined gravimetrically according to AOAC Method 982.27 (1990). Column chromatography was used to separate the non-polar (TAG) and polar (TPC) fractions. For each specific sample the analysis process was repeated three times.

\subsubsection{Composition of polar compounds}

The composition of polar compounds was assessed using high performance size exclusion chromatography (HPSEC) according to ISO Standard 16931 (2007). Separation was performed on a Finnigan Surveyor liquid chromatograph (Thermo Electron Corporation, Waltham, MA, USA). Components were separated onto three size exclusion Phenogel columns connected in series $(500 \mathrm{~A}, 100 \mathrm{~A}$ and $50 \mathrm{~A} ; 5 \mu \mathrm{m}, 300 \times 4.6 \mathrm{~mm}$; Phenomenex, Torrance, CA, USA) and kept at $30^{\circ} \mathrm{C}$. Tetrahydrofuran (THF) was used as the mobile phase at a flow rate of $0.3 \mathrm{~mL} / \mathrm{min}$. Sample of $10 \mu \mathrm{L}$ were injected, and eluting components were detected using an evaporative light scattering detector (Sedex 75 ; Sedere, Alfortville, France), operating at $30^{\circ} \mathrm{C}$ with purified air pressurized to $2.5 \times 10^{5} \mathrm{~N} / \mathrm{m}^{2}$. For each specific sample the whole analysis process was repeated three times.

\subsubsection{Tocopherols}

Tocopherols were analyzed according to AOCS Official Method Ce 8-89 (Firestone, 2009). Briefly, oil samples $(50 \mathrm{mg})$ were weighed directly into autosampler vials and dissolved in $1.0 \mathrm{~mL}$ of hexane. The analyses were performed on a Finnigan Surveyor HPLC (Thermo Electron Corp., Waltham,
MA, USA) with a Finnigan Surveyor Autosampler Plus and Finnigan Surveyor FL Plus fluorescence detector set for excitation at $292 \mathrm{~nm}$ and emission at $324 \mathrm{~nm}$. The column was a normal-phase Diol column $(5 \mu \mathrm{m} ; 250 \times 4.6 \mathrm{~mm}$; Monochrom, Varian, CA, USA). Each time a sample of $10 \mu \mathrm{L}$ was injected. The mobile phase consisted of $7 \%$ methyl-tert-butyl ether in hexane at a flow rate of $0.6 \mathrm{~mL} / \mathrm{min}$. For each specific sample the whole analysis process was repeated three times for averaging. The amounts of tocopherols were quantified using external calibration with each isomer calibrated individually.

\subsection{Statistical analyses}

Data was analyzed by single factor variance analysis (ANOVA) and regression analysis using Minitab 2000 statistical software (ver. 13.2, Minitab Inc, State College, PA, USA). Statistically significant differences between means were determined by Duncan's multiple range tests at the $P<0.05$ level.

\section{RESULTS AND DISCUSSION}

\subsection{Fatty acid composition}

The fatty acid composition of the nontransesterified mixture, zero-trans structured lipids and the commercial shortening are presented in Table 1.

The amounts of healthy unsaturated fatty acids which are beneficial for humans in the transesterification products were higher than in the commercial shortening by about $10.0-33.0 \%$.

Structuring the mixture of palm stearin and canola oil with stearic acid produced a 4-fold increase in the amount of stearic acid after transesterification. As a result its content in the structured lipids was comparable to the commercial shortening. As anticipated, trans fatty acids were not formed as a result of transesterification and their content in the structured lipids was as low as in the non-transesterified mixture and amounted to $0.5 \%$. Thus, in accordance with the US Food \& Drug Administration (Federal Register - 68 FR 41434, 2003), these products may be claimed zero-trans. The presence of trans isomers in the commercial shortening $(8.2 \%)$ indicated that it contained partially-hydrogenated fat (Gupta, 2017), although it was labelled as a zero-trans product. The GLC analysis revealed that the majority of trans fatty acids were elaidic acids (18:1, 9-trans).

\subsection{Triacylglycerol composition}

The triacylglycerol composition of the studied fats and the commercial shortening are presented in Table 2. The commercial shortening contained mainly LOO, LOP, OOO and POO, which amounted to $73.8 \%$ of the total TAGs. 
Development of zero-trans shortenings with high thermo-oxidative stability by enzymatic transesterification 5
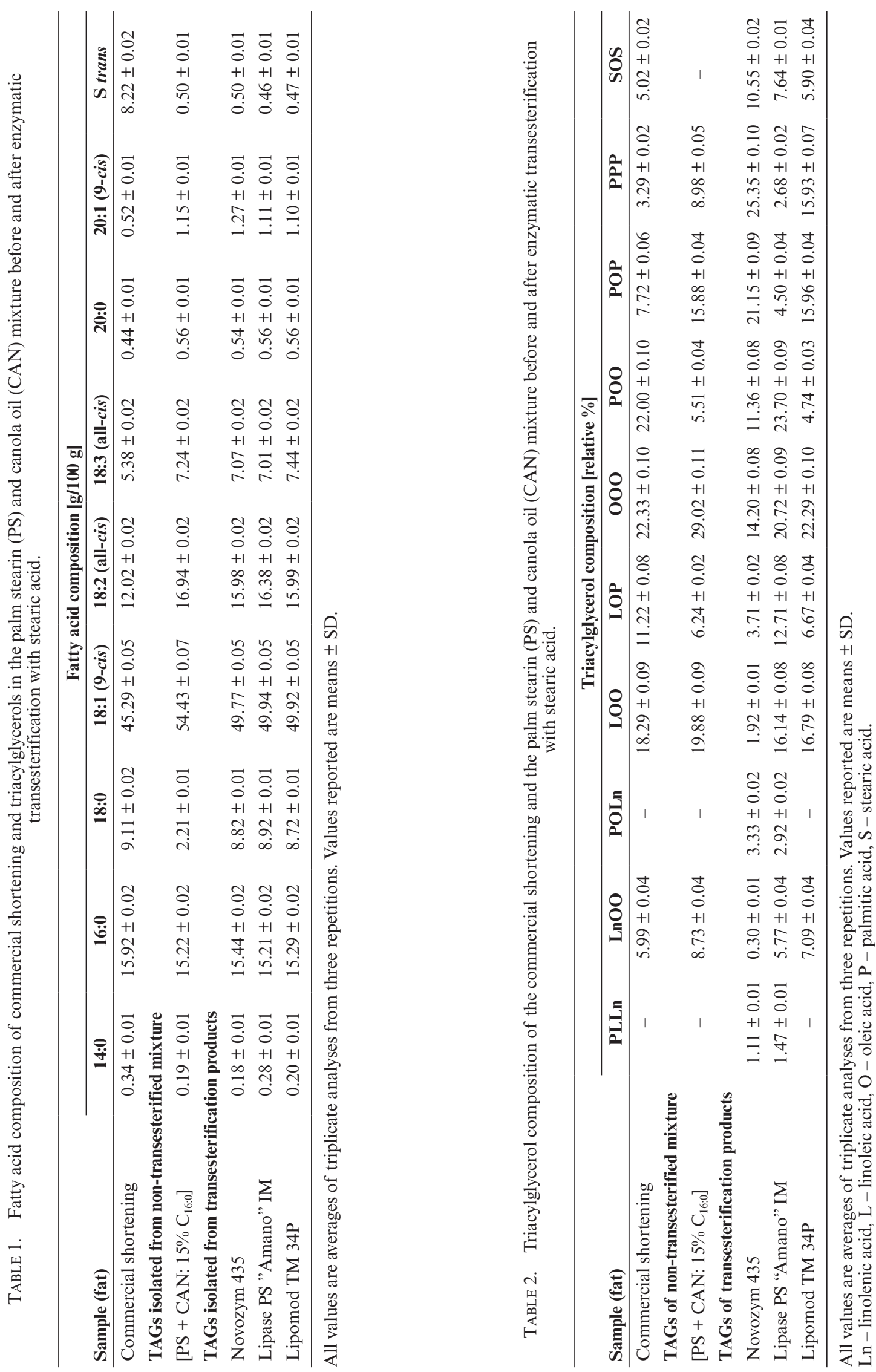

Grasas Aceites 71 (4), October-December 2020, e375. ISSN-L: 0017-3495 https://doi.org/10.3989/gya.0564191 
The palm stearin and canola oil mixture before transesterification consisted of the following TAG species: LnOO, LOO, LOP, OOO, POO, POP, PPP, and SOS, of which LOO and OOO were in the highest amounts and constituted $48.9 \%$ in total.

All the transesterification products contained new triacylglycerol SOS which was not present in the non-transesterified mixture. This proves that stearic acid was incorporated into TAG molecules and the transesterification occurred within the external positions of TAGs.

In the transesterification products obtained by the immobilized enzymes (Novozym 435 and Lipase PS "Amano" IM) new asymmetrical triacylglycerols were produced and contained palmitic acid in the molecules (PLLn, POLn). According to deMan (1992) the presence of such asymmetrical triacylglycerols (in which sn- 1 and sn-2 or sn-2 and sn-3 positions are occupied by two saturated or two unsaturated fatty acids) favors the desired polymorphic form $\beta^{\prime}$.

Compared to the commercial shortening, the transesterification structured lipids obtained from Novozym 435 were characterized by a much lower content of LnOO, LOO and LOP, and much higher content of POP, PPP, and SOS. For the transesterification products by Lipase PS "Amano" IM lower content of PPP was detected. PPP is one of the TAG species which exhibits a natural tendency to crystallize in an undesired polymorphic form $\beta$ (deMan, 1992). Form $\beta$ tends to constitute large crystals $(>50 \mu \mathrm{m})$, resulting in unattractive products which give the sensorial impression of sandy mouth feel (Ahmadi and Marangoni, 2009).

Transesterification performed by Lipomod TM $34 \mathrm{P}$ resulted in less pronounced changes in triacylglycerol composition with the exception of LOP and POO, whose content was significantly lower and POP and PPP exhibited the opposite trend.

\subsection{Solid fat content (SFC)}

Changes in the solid fat content as a function of temperature in the non-transesterified mixture, zero-trans structured lipids and commercial shortening are illustrated in Figure 1.

SFC profiles of the zero-trans structured lipids produced by immobilized lipases (Novozym 435 and Lipase PS "Amano" IM) were the closest match to those of the commercial shortening. This pattern

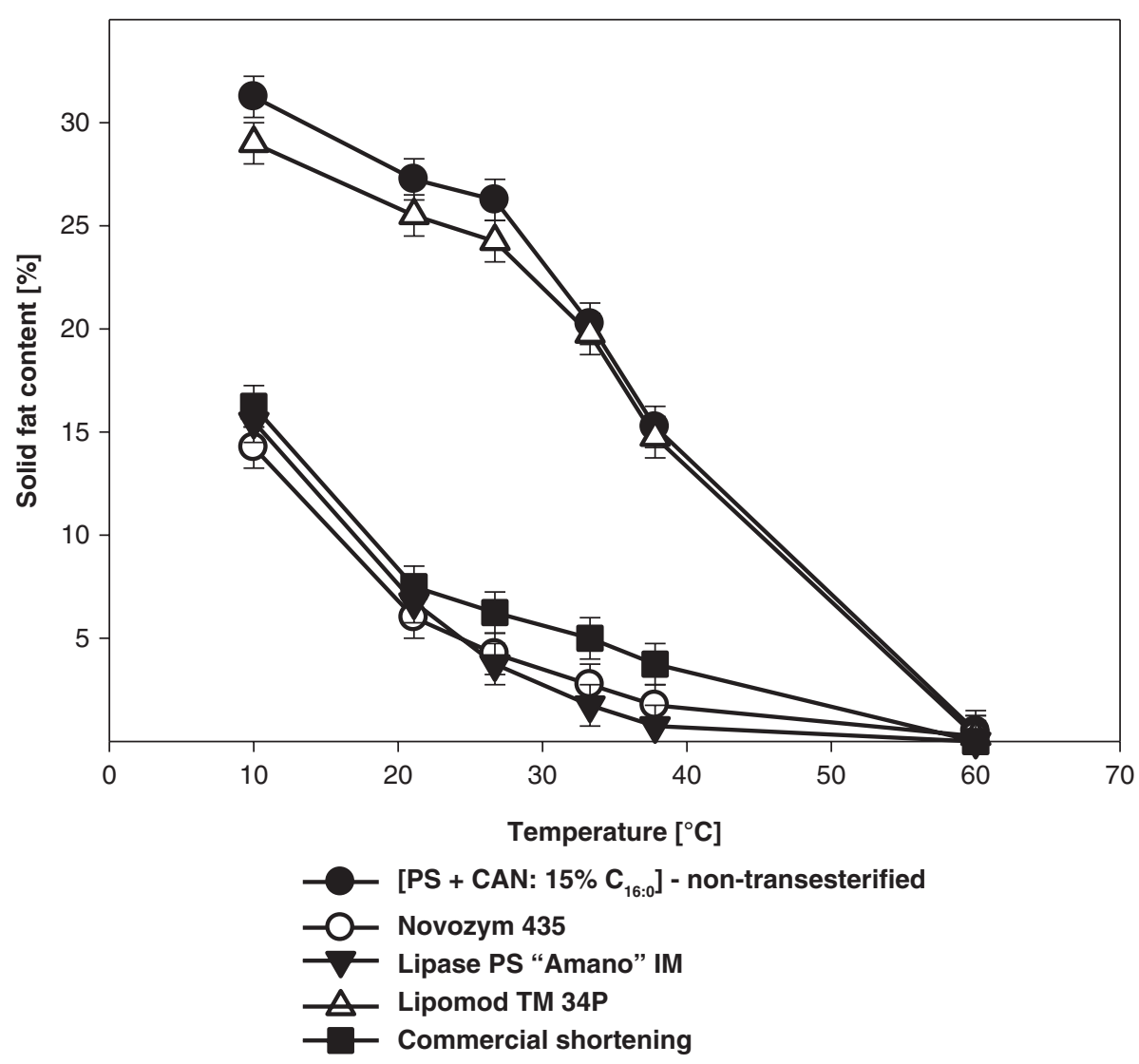

FIGURE 1. Solid fat content as a function of temperature for the commercial shortening and for triacylglycerols isolated from the [PS + CAN: $\left.15 \% \mathrm{C}_{16: 0}\right]$ mixture before and after enzymatic transesterification. Abbreviations: PS - palm stearin, CAN - canola oil, $\mathrm{C}_{16: 0}$ - palmitic acid. 
of SFC profiles as a function of temperature is characteristic of high stability fats which may be applied for frying or as confectionary fats (Metzroth, 2005). Furthermore, they tended to have lower SFC when compared to the non-transesterified mixture and showed a gradual slope with a wide plastic range from 10 to $60^{\circ} \mathrm{C}$. These changes are caused by fatty acid rearrangement within and among the TAG molecules during transesterification and creation of new lower melting TAG species (Aladedunye and Gruczynska, 2019).

\subsection{Crystal morphology}

The polarized light images of the zero-trans shortenings and the commercial shortening stored at temperature of $25^{\circ} \mathrm{C}$ (Figure 2) showed needleshaped crystals which were clearly separated from the amorphous phase and with a tendency to form agglomerates and heterogeneous distribution in the amorphous phase. After crystallisation at $5^{\circ} \mathrm{C}$ (Figure 3) needle-shaped crystals joined together into branched chains. Such a crystal morphology and the structural diversity of the triacylglycerols suggests that the zero-trans structured lipids most likely crystallize in the polymorphic form $\beta^{\prime}$. Hence the risk of granularity is reduced and the transesterification products become firm, stable and have a wide plasticity range.

In addition, the crystals grown at lower temperatures were smaller in size and homogenously distributed in the amorphous phase. Decreasing the size of the crystals resulted in a larger combined surface and a stronger network (Metzroth, 2005).

\subsection{Total polar compounds (after model frying fast test)}

Polar compounds are formed during the frying process. Since they remain in the fat, their presence is a reliable measure of the degree of thermal degradation. In addition, polar compounds are also formed during transesterification, therefore a noticeable increase in the TPC content was observed after the process. The study showed the higher the amount of water in the enzymatic preparation, the higher the TPC content after transesterification (Kowalski et al., 2004).

At the end of the model frying process the amount of TPCs was the highest after transesterification
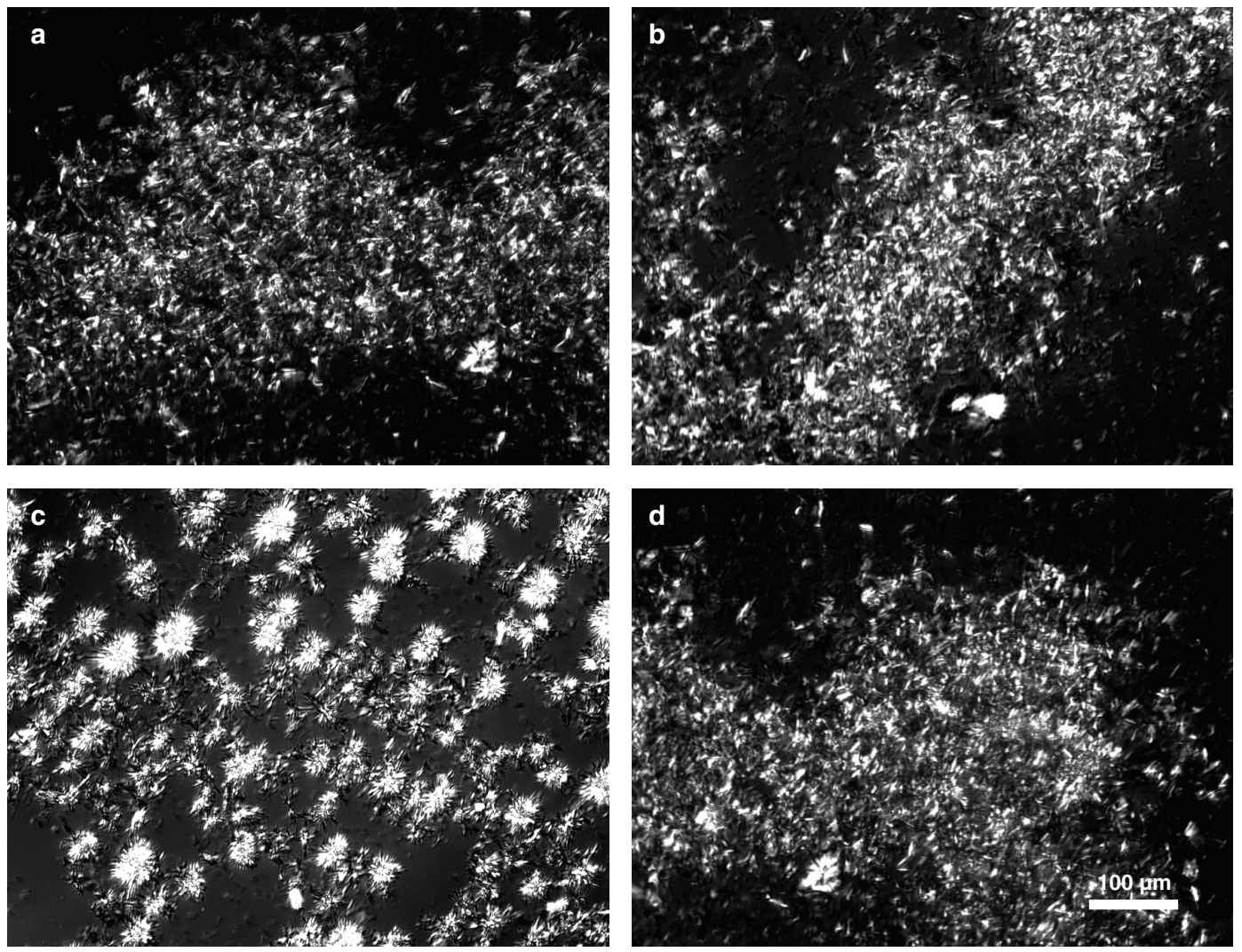

FIGURE 2. Polarized light micrographs of the zero-trans shortenings obtained from Novozym 435 (a),

Lipase PS "Amano" IM (b), Lipomod TM 34P (c), and of the commercial shortening (d) after crystallisation at $25^{\circ} \mathrm{C}$. 

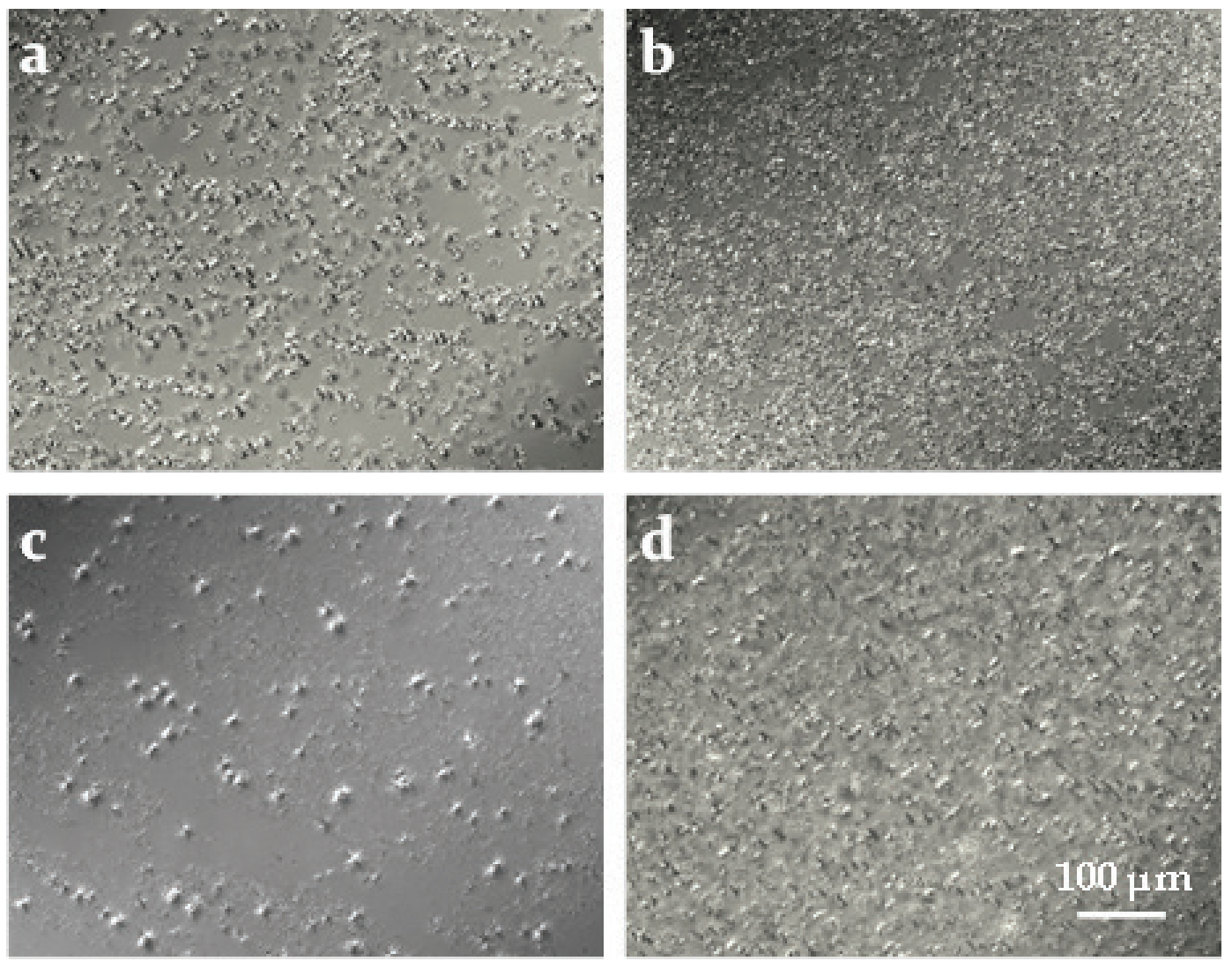

FIGURE 3. Polarized light micrographs of the zero-trans shortenings obtained from Novozym 435 (a), Lipase PS "Amano" IM (b), Lipomod TM 34P (c), and of the commercial shortening (d) after crystallization at $5^{\circ} \mathrm{C}$.

performed by Lipomod TM 34P and exceeded $25.0 \%$, which is regarded as borderline in the assessment of the quality of frying fats (Stier, 2013). The remaining zero-trans structured lipids (obtained by Novozym 435 and Lipase PS "Amano" IM) exhibited TPC contents similar to the commercial shortening and lower than the non-transesterified mixture at the final checkpoint (Table 3).

\subsection{Composition of polar compounds (after model frying fast test)}

The individual classes of polar compounds were separated as polymers, dimers, oxidized triacylglycerols (OTAGs), diacylglycerols (DAGs) and free fatty acids (FFAs). The amounts of specific compounds are presented in Table 3.

The zero-trans structured lipid formation of polymers was not observed until after the 30th or (for Novozym 435) even the 70th min of the model frying test. Regarding the commercial shortening, although polymer formation did not start until after 30 mins of model frying test, at the end of the process this product was characterized by the highest amount of polymers. The tendency for fat polymerization increases with the degree of unsaturation. However, although the transesterification products had higher amounts of oleic, linoleic and linolenic acids compared to the commercial shortening, they showed less formation of polymers throughout the model frying test, thus indicating that other factors beyond unsaturated fatty acid content were involved in the degradation of fats. Using a neural network system Przybylski and Zambiazi (2000) established that using fatty acid composition as the defining factor only $50 \%$ of the oil's thermooxidative stability can be predicted. However, after analyzing TAG composition, the transesterification structured lipids obtained from Novozym 435 were characterized as showing the lowest content of triunsaturated TAGs (LnOO, LOO, OOO) and the highest amount of monounsaturated (POP, SOS) and saturated (PPP) TAG species. As the most unsaturated TAGs are lost preferentially during heating and they generally form more polymers than the less unsaturated molecules (Martin et al., 1998), the transesterified products of Novozym 435 exhibited the latest start of polymer formation and formed the lowest amount of polymers, regardless of the duration of model frying. Furthermore, the 
TABLE 3. Formation of polar components and degradation of tocopherols during the model frying test for commercial shortening and the palm stearin (PS) and canola oil (CAN) mixture before and after enzymatic transesterification with stearic acid.

\begin{tabular}{|c|c|c|c|c|c|c|c|c|}
\hline \multirow[b]{2}{*}{ Sample (fat) } & \multirow{2}{*}{$\begin{array}{c}\text { Model } \\
\text { frying time } \\
\text { [min] }\end{array}$} & $\begin{array}{c}\text { TPCs } \\
{[\mathrm{g} / 100 \mathrm{~g}]}\end{array}$ & $\begin{array}{l}\text { Polymers } \\
{[\mathrm{g} / 100 \mathrm{~g}]}\end{array}$ & $\begin{array}{c}\text { Dimers } \\
{[\mathrm{g} / 100 \mathrm{~g}]}\end{array}$ & $\begin{array}{c}\text { OTAGs } \\
\text { [g/100 g] }\end{array}$ & $\begin{array}{c}\text { DAGs } \\
{[\mathrm{g} / 100 \mathrm{~g}]}\end{array}$ & $\begin{array}{c}\text { FFAs } \\
{[\mathrm{g} / 100 \mathrm{~g}]}\end{array}$ & $\begin{array}{c}\text { RTOCs } \\
{[\mu \mathrm{g} / \mathrm{g}]}\end{array}$ \\
\hline & & \multicolumn{7}{|c|}{ All the above units, i.e. $[\mathrm{g} / 100 \mathrm{~g}]$ and $[\mu \mathrm{g} / \mathrm{g}]$, refer to fat mass } \\
\hline \multirow{4}{*}{$\begin{array}{l}\text { Commercial } \\
\text { shortening }\end{array}$} & 0 & $8.4 \pm 0.9^{f}$ & $0.0 \pm 0.0^{\mathrm{h}}$ & $4.6 \pm 0.7^{\mathrm{d}}$ & $3.4 \pm 0.6^{\mathrm{g}}$ & $0.2 \pm 0.0^{j}$ & $0.01 \pm 0.00^{\mathrm{i}}$ & $672 \pm 13$ \\
\hline & 30 & $12.0 \pm 1.2^{\mathrm{e}}$ & $0.0 \pm 0.0^{\mathrm{h}}$ & $6.8 \pm 1.0^{\mathrm{c}}$ & $4.3 \pm 0.7^{\mathrm{f}}$ & $0.4 \pm 0.1^{\mathrm{h}}$ & $0.01 \pm 0.00^{\mathrm{i}}$ & $104 \pm 2$ \\
\hline & 70 & $13.9 \pm 1.4^{\mathrm{d}}$ & $1.0 \pm 0.2^{\mathrm{e}}$ & $7.9 \pm 1.2^{\mathrm{b}}$ & $4.3 \pm 0.7^{\mathrm{f}}$ & $0.5 \pm 0.1^{\mathrm{h}}$ & $0.04 \pm 0.01^{\mathrm{g}}$ & $5 \pm 1$ \\
\hline & 120 & $20.7 \pm 1.7^{\mathrm{b}}$ & $3.6 \pm 0.5^{\mathrm{a}}$ & $11.9 \pm 1.6^{\mathrm{a}}$ & $4.0 \pm 0.7^{\mathrm{f}}$ & $0.9 \pm 0.1^{\mathrm{f}}$ & $0.12 \pm 0.02^{\mathrm{d}}$ & $5 \pm 1$ \\
\hline \multirow{4}{*}{$\begin{array}{l}{[\mathrm{PS}+\mathrm{CAN}:} \\
15 \% \mathrm{C}_{16: 0} \text { - } \\
\text { transesterified }\end{array}$} & 0 & $3.3 \pm 0.4^{\mathrm{i}}$ & $0.0 \pm 0.0^{\mathrm{h}}$ & $0.8 \pm 0.2^{\mathrm{i}}$ & $2.3 \pm 0.4^{\mathrm{h}}$ & $0.1 \pm 0.0^{\mathrm{k}}$ & $0.00 \pm 0.00^{\mathrm{j}}$ & $722 \pm 11$ \\
\hline & 30 & $6.3 \pm 0.7^{\mathrm{g}}$ & $0.1 \pm 0.0^{\mathrm{g}}$ & $1.5 \pm 0.3^{\mathrm{h}}$ & $4.6 \pm 0.6^{\mathrm{e}}$ & $0.1 \pm 0.0^{\mathrm{k}}$ & $0.01 \pm 0.00^{\mathrm{i}}$ & $336 \pm 7$ \\
\hline & 70 & $13.8 \pm 1.4^{\mathrm{d}}$ & $0.7 \pm 0.1^{\mathrm{e}}$ & $3.3 \pm 0.6^{\mathrm{f}}$ & $9.2 \pm 1.3^{\mathrm{c}}$ & $0.3 \pm 0.0^{\mathrm{i}}$ & $0.04 \pm 0.01^{\mathrm{g}}$ & $184 \pm 4$ \\
\hline & 120 & $23.7 \pm 1.9^{\mathrm{a}}$ & $2.0 \pm 0.3^{\mathrm{c}}$ & $5.8 \pm 0.9^{c}$ & $14.7 \pm 1.8^{\mathrm{a}}$ & $0.8 \pm 0.1^{\mathrm{f}}$ & $0.16 \pm 0.03^{\mathrm{c}}$ & $27 \pm 2$ \\
\hline \multirow[t]{4}{*}{ Novozym 435} & 0 & $5.7 \pm 0.6^{\mathrm{h}}$ & $0.0 \pm 0.0^{\mathrm{h}}$ & $1.4 \pm 0.3^{\mathrm{h}}$ & $3.8 \pm 0.6^{\mathrm{f}}$ & $0.3 \pm 0.0^{\mathrm{i}}$ & $0.04 \pm 0.01^{\mathrm{g}}$ & $433 \pm 9$ \\
\hline & 30 & $11.7 \pm 1.2^{\mathrm{e}}$ & $0.0 \pm 0.0^{\mathrm{h}}$ & $3.1 \pm 0.5^{\mathrm{f}}$ & $7.5 \pm 1.1^{\mathrm{d}}$ & $0.7 \pm 0.1^{\mathrm{g}}$ & $0.08 \pm 0.02^{\mathrm{f}}$ & $139 \pm 3$ \\
\hline & 70 & $15.6 \pm 1.4^{\mathrm{c}}$ & $0.0 \pm 0.0^{\mathrm{h}}$ & $4.2 \pm 0.7^{\mathrm{e}}$ & $9.5 \pm 1.2^{\mathrm{c}}$ & $1.1 \pm 0.1^{\mathrm{e}}$ & $0.15 \pm 0.03^{\mathrm{d}}$ & $87 \pm 3$ \\
\hline & 120 & $21.5 \pm 1.7^{\mathrm{b}}$ & $1.5 \pm 0.2^{\mathrm{d}}$ & $5.9 \pm 0.9^{c}$ & $11.7 \pm 1.5^{\mathrm{b}}$ & $1.9 \pm 0.2^{\mathrm{c}}$ & $0.26 \pm 0.05^{\mathrm{b}}$ & $3 \pm 1$ \\
\hline \multirow{4}{*}{$\begin{array}{l}\text { Lipase PS } \\
\text { "Amano" IM }\end{array}$} & 0 & $6.4 \pm 0.7^{\mathrm{g}}$ & $0.0 \pm 0.0^{\mathrm{h}}$ & $2.1 \pm 0.4^{\mathrm{g}}$ & $3.9 \pm 0.6^{\mathrm{f}}$ & $0.3 \pm 0.0^{\mathrm{i}}$ & $0.03 \pm 0.01^{\mathrm{h}}$ & $417 \pm 8$ \\
\hline & 30 & $8.8 \pm 1.0^{\mathrm{f}}$ & $0.0 \pm 0.0^{\mathrm{h}}$ & $3.0 \pm 0.6^{\mathrm{f}}$ & $5.2 \pm 0.8^{\mathrm{e}}$ & $0.5 \pm 0.1^{\mathrm{h}}$ & $0.05 \pm 0.01^{\mathrm{g}}$ & $98 \pm 3$ \\
\hline & 70 & $14.8 \pm 1.5^{\mathrm{c}}$ & $0.8 \pm 0.1^{\mathrm{e}}$ & $5.6 \pm 1.0^{\mathrm{d}}$ & $7.1 \pm 1.1^{\mathrm{d}}$ & $0.9 \pm 0.1^{\mathrm{f}}$ & $0.11 \pm 0.02^{\mathrm{e}}$ & $46 \pm 3$ \\
\hline & 120 & $21.9 \pm 1.8^{\mathrm{b}}$ & $2.8 \pm 0.4^{\mathrm{b}}$ & $8.5 \pm 1.3^{b}$ & $8.5 \pm 1.3^{c}$ & $1.5 \pm 0.2^{\mathrm{d}}$ & $0.18 \pm 0.03^{\mathrm{c}}$ & $5 \pm 1$ \\
\hline \multirow{4}{*}{$\begin{array}{l}\text { Lipomod } \\
\text { TM 34P }\end{array}$} & 0 & $7.2 \pm 0.8^{\mathrm{g}}$ & $0.0 \pm 0.0^{\mathrm{h}}$ & $1.9 \pm 0.4^{\mathrm{h}}$ & $4.1 \pm 0.7^{\mathrm{f}}$ & $0.8 \pm 0.1^{\mathrm{f}}$ & $0.06 \pm 0.01^{\mathrm{f}}$ & $403 \pm 8$ \\
\hline & 30 & $9.3 \pm 1.0^{\mathrm{f}}$ & $0.0 \pm 0.0^{\mathrm{h}}$ & $2.5 \pm 0.5^{\mathrm{g}}$ & $4.9 \pm 0.8^{\mathrm{e}}$ & $1.5 \pm 0.2^{\mathrm{d}}$ & $0.09 \pm 0.02^{\mathrm{e}}$ & $110 \pm 2$ \\
\hline & 70 & $14.8 \pm 1.5^{\mathrm{c}}$ & $0.5 \pm 0.1^{\mathrm{f}}$ & $4.4 \pm 0.8^{\mathrm{e}}$ & $6.6 \pm 1.1^{\mathrm{d}}$ & $2.5 \pm 0.3^{\mathrm{b}}$ & $0.20 \pm 0.04^{\mathrm{c}}$ & $53 \pm 3$ \\
\hline & 120 & $25.3 \pm 2.0^{\mathrm{a}}$ & $2.7 \pm 0.4^{b}$ & $7.6 \pm 1.2^{\mathrm{b}}$ & $9.8 \pm 1.5^{\mathrm{c}}$ & $4.5 \pm 0.5^{\mathrm{a}}$ & $0.42 \pm 0.08^{\mathrm{a}}$ & $4 \pm 1$ \\
\hline
\end{tabular}

All values are averages of triplicate analyses from three repetitions. Values reported are means \pm SD. Testing conditions: temperature $180 \pm 5{ }^{\circ} \mathrm{C}$, stirring at $400 \mathrm{rpm}$, the ratio of oil/fat surface to volume at 0.42 . TPCs - total polar compounds, OTAGs - oxidized triacylglycerols, DAGs - diacylglycerols, FFAs - free fatty acids, RTOCs - residual tocopherols. Values with different superscript letters $(\mathrm{a}-\mathrm{k})$ within each column are statistically significantly different at $P<0.05$.

highest POP and SOS contents in those lipids confer an extra advantage since oleic acid, the fatty acid capable of polymerization, was lost to a lower extent from the central position of the TAG molecule than from external positions.

These results led to the conclusion that under model frying conditions the effect of TAG composition on polymer formation is much more important than that of the unsaturated fatty acid content (Martin et al., 1998).

The amount of dimers and oxidized triacylglycerols consistently increased throughout the model frying period. As model frying progressed, the transesterified products were characterized by higher content of oxidized triacylglycerols compared to the commercial frying shortening. The zero-trans transesterification structured lipids were characterized by higher unsaturated fatty acid contents compared to the commercial frying shortening. Furthermore, transesterified products obtained from immobilized enzymes alone contained new diunsaturated triacylglycerols (PLLn, POLn) which unprotected against oxidation. These differences between enzymatically modified fats and the commercial shortening were translated into the different contents in oxidized triacylglycerols.

Taking into account the sum of polymers, dimers and oxidized triacylglycerols after the 70th and 120th min of the model frying test, it was noticeable that the frying performance of the transesterification structured lipids was similar to that of the commercial shortening. Lipomod TM $34 \mathrm{P}$ seemed only to produce higher amounts of thermo-oxidation compounds than the commercial shortening at the end of the assay.

Free fatty acids were formed during the hydrolysis of TAGs. For each of the fats tested the FFA contents FFAs increased consistently throughout the model frying test period. At the end of frying the transesterification structured lipids were characterized by higher amounts of FFAs compared to the commercial frying shortening.

\subsection{Tocopherols (after model frying fast test)}

Tocopherols are the major antioxidants present in refined oils and offer protection against thermo-oxidative degradation mainly by donating 
hydrogen atoms to lipid peroxy radicals, thereby interfering with either chain propagation or initiation (Seppanen et al., 2010). The changes in total tocopherol contents during the model frying of the non-transesterified mixture, zero-trans structured lipids and the commercial shortening are shown in Table 3. For all the zero-trans structured lipids and non-transesterified mixture the rates of tocopherol depletion were lower than for the commercial shortening. The faster tocopherol degradation in the commercial frying shortening may be related to its lower content of unsaturated fatty acids since tocopherols are known to degrade faster as the level of unsaturation in oil decreases (Barrera-Arellano et al., 2002). This phenomenon can be attributed to the non-selective oxidation of unsaturated fatty acids and tocopherols by the highly reactive alkoxyl and hydroxyl radicals generated by the decomposition of hydroperoxides. Other mechanisms of tocopherol disappearance during frying can be related to the increase in the rate of oxidative initiation and propagation, producing high concentrations of lipid peroxy radicals, which in turn place an increasing demand on the number of tocopherol molecules participating in the antioxidant activity (Verleyen et al., 2002). It was also reported that tocopherols had very low volatility under frying conditions and hence their rapid loss was due to degradation (Marmesat et al., 2010). In the present study the faster degradation of tocopherols such as in the commercial frying shortening did not result in more rapid development of polar compounds during frying.

Among the fats assayed the tocopherols disappeared most quickly from the commercial shortening, where despite relatively high initial residual tocopherol (RTOCs) levels, their remains were already negligible after 70 mins of model frying. All the transesterified products performed similarly to one another, having reached negligible values of RTOCs at the final checkpoint (after 120 mins of frying). A positive exception was observed for the non-transesterified mixture, where even after 120 mins of model frying the RTOC level was noted at the value of $27 \mu \mathrm{g} / \mathrm{g}$.

\section{CONCLUSIONS}

Enzymatic transesterification by both the immobilized and non-immobilized lipases offered potential in the production of novel zero-trans structured lipids that could be used for high temperature applications. Furthermore, the immobilized enzymes (Novozym 435 and Lipase PS "Amano" IM) performed better overall the than non-immobilized lipase (Lipomod TM 34P). When compared to the commercial frying shortening, the transesterification products showed similar frying performance.
Not only did the transesterification products have comparable solid fat content profiles and crystal morphology to those of the commercial shortening, but were also characterized by the absence of trans isomers, higher contents of oleic and linolenic acids, a lower rate of polymer formation and a lower rate of tocopherol disappearance during frying, all of which may be considered as additional benefits to human health.

The development of frying shortenings by lipasecatalyzed transesterification may have great industrial relevance, especially if large-scale continuous, solvent free, immobilized enzyme reactors are used. Therefore, the introduction of inexpensive enzymatic preparations and the optimization of the large-scale lipase bioreactors, while controlling the water content (or water activity) in the reaction system, should convince the food industry to switch from hydrogenation to the lipase-mediated technology of high stability zero-trans shortenings.

\section{ACKNOWLEDGMENTS}

This work was financially supported by grants from the Alberta Funding Consortium and the Alberta Value Added Corporation.

\section{REFERENCES}

Ahmadi L, Marangoni AG. 2009. Functionality and physical properties of interesterified high oleic shortening structured with stearic acid. Food Chem. 117, 668-673. https:// doi.org/10.1016/j.foodchem.2009.04.072

Aladedunye F, Gruczynska E. 2019. Configuring phenolic antioxidants for frying applications, in Varelis P, Melton L, Shahidi F (Eds.). Encyclopedia of Food Chemistry. Elsevier, 54-62. https://doi.org/10.1016/B978-0-08-1005965.21659-4

Aladedunye FA, Przybylski R. 2011. Rapid assessment of frying performance using small size samples of oils/fats. J. Am. Oil Chem. Soc. 88, 1867-1873. https://doi.org/10.1007/ s11746-011-1874-0

AOAC. 1990. Official methods of analysis of the Association of Official Analytical Chemists. 15th ed. Arlington, VA, USA.

Barrera-Arellano D, Ruiz-Méndez V, Velasco J, Márquez-Ruiz G, Dobarganes C. 2002. Loss of tocopherols and formation of degradation compounds at frying temperatures in oils differing in degree of unsaturation and natural antioxidant content. J. Sci. Food Agric. 82, 1696-1702. https://doi.org/10.1002/jsfa.1245

Bonanom A, Grundy SM. 1988. Effect of dietary stearic acid on plasma cholesterol and lipoprotein levels. N. Engl. J. Med. 318, 1244-1248. https://doi.org/10.1056/NEJM 198805123181905

Chavarro JE, Stampfer MJ, Campos H, Kurth T, Willett WC, Ma J. 2008. A prospective study of trans-fatty acid levels in blood and risk of prostate cancer. Cancer Epidemiol. Biomarkers Prev. 17, 95-101. https://doi.org/10.1158/10559965.EPI-07-0673

deMan JM. 1992. X-ray diffraction spectroscopy in the study of fat polymorphism. Food Res. Int. 25, 471-476. https://doi. org/10.1016/0963-9969(92)90172-2

Eckel RH, Borra S, Lichtenstein AH, Yin-Piazza SY. 2007. Understanding the complexity of trans fatty acid reduction in the American diet: American Heart Association Trans Fat Conference 2006: Report of the Trans Fat Conference Planning Group. Circulation 115, 2231-2246. https://doi. org/10.1161/CIRCULATIONAHA.106.181947 
Firestone D. 2009. Official Methods and Recommended Practices of the American Oil Chemists' Society. 6th ed. Champaign, IL, USA.

Food \& Drug Administration. 2003. Guidance for Industry. Food Labelling: Trans Fatty Acids in Nutrition Labelling, Nutrient Content Claims, and Health Claims. US Department of Health and Human Services. Federal Register 68, 41433-41506.

Gupta MK. 2017. Trans fats alternatives and challenges, in Gupta MK (Ed.) Practical Guide to Vegetable Oil Processing. AOCS Press, 341-374. https://doi.org/10.1016/ B978-1-63067-050-4.00013-1

Hegsted DM, McGandy RB, Myers ML, Stare FJ. 1965. Quantitative effects of dietary fat on serum cholesterol in man. Am. J. Clin. Nutr. 17, 281-295. https://doi.org/10.1093/ ajen/17.5.281

Idris NA, Berger KG, Ong ASH. 1989. Evaluation of shortenings based on various palm oil products. $J$ Sci. Food Agric. 46, 481-493. https://doi.org/10.1002/jsfa. 2740460410

ISO. 2007. Animal and Vegetable Fats and Oils - Determination of Polymerized Triglycerides Content by High Performance Size Exclusion Chromatography (HPSEC). Geneva, International Organization for Standardization [Standard 16931].

Kowalska D, Kostecka M, Tarnowska K, Kowalski B. 2014. Oxidative stabilities of enzymatically interesterified goose fat and rapeseed oil blend by rancimat and PDSC. J. Therm. Anal. Calorim. 115, 2063-2070. https://doi.org/10.1007/ s10973-013-3125-0

Kowalski B, Tarnowska K, Gruczyńska E, Bekas W. 2004. Chemical and enzymatic interesterification of a beef tallow and rapeseed oil equal-weight blend. Eur. J. Lipid Sci. Technol. 106, 655-664. https://doi.org/10.1002/ejlt. 200400973

Lichtenstein AH, Appel LJ, Brands M, Carnethon M, Daniels S, Franch HA, Franklin B, Kris-Etherton P, Harris WS, Howard B, Karanja N, Lefevre M, Rudel L, Sacks F, Van Horn L, Winston M, Wylie-Rosett J. 2006. Diet and lifestyle recommendations. Circulation 114, 82-96. https:// doi.org/10.1161/CIRCULATIONAHA.106.176158

Marmesat S, Morales A, Velasco J, Dobarganes MC. 2010. Action and fate of natural and synthetic antioxidants during frying. Grasas Aceites 61, 333-340. https://doi.org/ $10.3989 /$ gya. 021910

Martin JC, Dobarganes MC, Nour M, Márquez-Ruiz G, Christie WW, Lavillonnière F, Sébédio JL. 1998. Effect of fatty acid positional distribution and triacylglycerol composition on lipid by-products formation during heat treatment: I. Polymer formation. J. Am. Oil Chem. Soc. 75, 1065-1071. https://doi.org/10.1007/s11746-998-0114-8

Metzroth D. 2005. Shortenings: Science and technology, in Shahidi F (Ed.) Bailey's Industrial Oil and Fat Products. A John Wiley \& Sons Inc., Hoboken, New Jersey. https://doi. org/10.1002/047167849X.bio044

Przybylski R, Zambiazi RC. 2000. Predicting oxidative stability of vegetable oils using neural network system and endogenous oil components. J. Am. Oil Chem. Soc. 77, 925-931. https://doi.org/10.1007/s11746-000-0146-x

Seppanen CM, Song Q, Csallany AS. 2010. The antioxidant functions of tocopherol and tocotrienol homologues in oils, fats, and food system. J. Am. Oil Chem. Soc. 87, 469-481. https://doi.org/10.1007/s11746-009-1526-9

Stier RF. 2013. Ensuring the health and safety of fried foods. Eur. J. Lipid Sci. Technol. 115, 956-964. https://doi.org/10.1002/ ejlt.201300180

Uauy R, Aro A, Clarke R, Ghafoorunissa R, L'Abbé M, Mozaffarian D, Skeaff M, Stender S, Tavellaet M. 2009. WHO scientific update on trans fatty acids: summary and conclusions. Eur. J. Clin. Nutr. 63, S68-S75. https://doi.org/ $10.1038 /$ ejen.2009.15

Verleyen T, Kamal-Eldin A, Mozuraityte R, Verhe R, Dewettinck K, Huyghebaert A, De Greyt W. 2002. Oxidation at elevated temperatures: competition between $\alpha$-tocopherol and unsaturated triacylglycerols. Eur. J. Lipid Sci. Technol. 104, 228-233. https://doi.org/10.1002/14389312(200204)104:4\%3C228::AID-EJLT228\%3E3.0.CO;2-5 